\title{
PENERAPAN MODEL PEMBELAJARAN KOOPERATIF TIPE GROUP INVESTIGASI UNTUK MENINGKATKAN AKTIVITAS DAN HASIL BELAJAR MATEMATIKA
}

\author{
IMPLEMENTATION OF COOPERATIVE LEARNING MODEL TYPE GROUP \\ INVESTIGATION TO INCREASE MATHEMATICS LEARNING ACTIVITIES AND \\ OUTCOMES
}

\author{
Yayah Haryati \\ Sekolah Menengah Atas Negeri 6 Bandung, Bandung, Indonesia \\ y_haryati@gmail.com
}

\begin{abstract}
ABSTRAK
Pembelajaran Matematika harus membangun proses komunikasi aktif antara guru sebagai pengajar dan siswa sebagai pelajar. Namun pada kenyataannya hasil belajar siswa belum menunjukkan hasil yang memuaskan. Oleh karena itu, perlu dicari model pembelajaran yang lebih baik, dan dapat meningkatkan prestasi belajar siswa. Tujuan penelitian ini adalah untuk meningkatkan aktivitas dan hasil belajar Matematika melalui penerapan model pembelajaran kooperatif tipe group investigasi. Metode penelitian yang digunakan adalah penelitian tindakan kelas mengunakan sistem spiral refleksi model Kemmis dan Mc Taggart yang dilakukan dari tindakan I, tindakan II dan tindakan III. Penelitian ini dilaksanakan dari tanggal 11 Desember 2017 - 8 Januari 2018. Adapun subyek penelitian dalam penelitian ini adalah siswa kelas XI MIPA 7 SMA Negeri 6 Bandung tahun ajaran 2017/2018 sebanyak 30 orang. Hasil penelitian menunjukkan bahwa penggunaan model pembelajaran kooperatif tipe group investigasi, pada aktivitas proses pembelajaran Matematika dan nilai siswa mengalami peningkatan dari tindakan I, tindakan II, dan tindakan III. Dari hasil penelitian dapat disimpulkan bahwa penerapan model pembelajaran kooperatif tipe group investigasi telah meningkatkan aktivitas dan hasil belajar Matematika. Berdasarkan kesimpulan tersebut, peneliti merekomendasikan untuk menerapkan model pembelajaran kooperatif tipe group investigasi di kelas lain, sehingga peningkatan pembelajaran dapat terjadi secara menyeluruh.
\end{abstract}

Kata Kunci: model pembelajaran, kooperatif tipe group investigasi, aktivitas dan hasil belajar

\begin{abstract}
Mathematics learning have to build an active communication process between teachers and students. But in fact student learning outcomes have not shown satisfactory results. Therefore, it is necessary to find a better learning model that can improve student achievement. The purpose of this resaerch is to improve the activity and learning of Mathematics through the implement of cooperative learning model type investigation group. The research method used is classroom action research using spiral reflection system of Kemmis and Mc Taggart model that is done from action I, action II and action III. This research was conducted from December 11, 2017 - January 8, 2018. The subject of this research is the students of natural science class XI at Public High School 6 Bandung academic year 2017/2018 as many as 30 students. The result of this research shows that the use of cooperative learning model of investigative group type on the learning process of mathematics activity and the students score have increased from action I, action II, and action III. The result of the research shows that the implamantion of cooperative learning model of investigative group type on the learning process of mathematics activity and the students score have increased from action I, action II, and action III. from this conclusion the researcher recommends to implement cooperative learning model of group type of investigation in other class, so that improvement of learning can happen comprehensive.
\end{abstract}

Keywords: learning model, cooperative type of investigative group, activity and learning outcomes 


\section{PENDAHULUAN}

Proses pendidikan di sekolah mempunyai peranan yang penting untuk mengembangkan kemampuan dan keterampilan serta membentuk sikap peserta didik. Dengan demikian sekolah sebagai ujung tombak pendidikan berperan dan bertanggung jawab terhadap perkembangan seluruh aspek kepribadian siswa melalui proses pendidikan dan pengajaran di sekolah (Dahar, 1985; Winkell, 1993 \& Udin, 1992). Oleh karena itu dalam pembelajaran Matematika, proses pembelajarannya harus berlangsung aktif dan multi arah antara siswa dengan siswa serta dengan guru.

Proses belajar mengajar Matematika memiliki tujuan yang ideal yaitu agar peserta didik memiliki pemahaman, kesadaran dan wawasan (Abdurrahman, 1989 \& Udin, 1992). Pembelajaran Matematika harus membangun proses komunikasi yang aktif terjadi antara guru sebagai pengajar dan siswa sebagai pelajar atau peserta didik harus berlangsung harmonis (Hariyanto, 2000 \& Sumantri dan Permana, 2001). Namun pada kenyataannya hasil belajar siswa mata pelajaran Matematikakelas XI, khususnya KD 3.9 yaitu menganalisis keberkaitan turunan pertama fungsi dengan nilai maksimum, nilai minimum, dan selang kemonotonan fungsi, serta kemiringan garis singgung kurva, pada umumnya belum menunjukkan hasil yang memuaskan dan prestasi belajar beberapa siswa masih tergolong memprihatinkan dibawah nilai KKM. Hal ini disebabkan karena Model pembelajaran yang diterapkan saat ini oleh sebagian besar guru cenderung menggunakan model pembelajaran biasa atau konvensional yang lebih terfokus pada guru, sehingga kegiatan pembelajaran menjadi kurang efektif, selain itu hal ini menyebabkan siswa tidak mampu berpikir lebih tinggi (Retno, 2003). Padahal Sato (2014) menjelaskan bahwa seharusnya pembelajaran dikembangkan secara autentik, yang berarti pembelajaran harus disesuaikan dengan karakteristik pembelajaran itu sendiri.

Berbagai upaya ke arah peningkatan pembelajaran Matematika terus dilakukan yaitu dengan perbaikan terhadap strategi, metode, model pembelajaran, serta teknik pelaksanaan pembelajaran yang menekankan pada penggunaan strategi yang dapat mengaktifkan siswa dalam pembelajaran Matematika (Harianto, 2000). Rendahnya nilai rata-rata kelas di atas, terjadi karena mereka kurang memperoleh latihan-latihan untuk meningkatkan kemampuan bernalar, berpikir lebih tinggi, dan kemampuan berinteraksi (kemampuan sosial) (Arikunto, 2003). Oleh karena itu, perlu dicari model pembelajaran yang lebih baik, dan dapat meningkatkan prestasi belajar siswa.

Salah satu model pembelajaran yang dapat meningkatkan aktivitas bekerjasama antar siswa, daya nalar, dan kemampuan berpikir adalah model pembelajaran kooperatif tipe group investigasi, karena menurut Kronberg dan Griffin (2000) bahwa model group investigasi ini mendorong siswa untuk mengumpulkan informasi untuk memecahkan masalah dan mengaktifkan kemampuan berpikir tinggi. Dengan kata lain, model pembelajaran kooperatif tipe group investigasi ini dapat menyediakan lingkungan belajar yang kondusif untuk terjadinya interaksi belajar mengajar yang lebih efektif, sehingga siswa dapat membangun sendiri 
pengetahuannya (Hariyanto, 2000; Slavin, 2010 \& Saraswati, 2000). Di sisi lain, untuk meningkatkan kualitas pembelajaran melalui penerapan model group investigasi dalam pembelajaran dapat dilakukan melalui Lesson Study yaitu sebuah upaya untuk memperbaiki proses pembelajaran yang dilakukan oleh sekelompok guru secara kolaboratif dan berkelanjutan dalam merencanakan, melakukan, mengamati, dan melaporkan hasil belajar (Cerbin \& Kopp, 2006; Ono \& Ferreira, 2010; Murtiani et al., 2012).

Sebuah penelitian dari Wasamana dan Nurihsan (2016) menunjukkan bahwa pembelajaran investigasi kelompok telah terbukti meningkatkan hampir semua indikator kecakapan sosial siswa Sekolah Dasar. Dalam penelitian Asyari (2016) dijelaskan bahwa penerapan model group investigasi dan problem based learning secara bersama-sama telah mendorong siswa untuk berpikir kritis melalui merencanakan, berdebat, mengemukakan pertanyaan dan masalah, dan menganalisa dan memberikan solusi kepada lingkungan sekitarnya.

Berdasarkan latar belakang di atas, peneliti terdorong untuk menerapkan model pembelajaran kooperatif tipe group investigasi pada pembelajaran Matematika siswa Kelas XI MIPA 7 SMA Negeri 6 Bandung melalui Penelitian Tindakan Kelas (PTK). Adapun tujuan dari penelitian ini adalah untuk: (1) meningkatkan aktivitas dan hasil belajar Matematika dengan penerapan model pembelajaran kooperatif tipe group investigasi pada siswa kelas XI MIPA 7 SMA Negeri 6 Bandung; (2) Mengetahui tanggapan siswa kelas XI MIPA
7 SMA Negeri 6 Bandung pada penerapapan model pembelajaran kooperatif tipe group investigasi; dan (3) Mengetahui perubahan dalam pembelajaran Matematika di kelas XI MIPA 7 SMA Negeri 6 Bandung setelah menggunakan model belajar kooperatif tipe group investigasi.

\section{METODE PENELITIAN}

Metode penelitian yang digunakan adalah Penelitian Tindakan Kelas (PTK). PTK bersifat situasional yaitu berkaitan dengan diagnosis masalah dalam konteks tertentu dan berusaha menyelesaikannya dalam konteks itu. Dengan kata lain, penelitian ini biasanya dilakukan oleh guru dalam kelas melalui refleksi diri dengan tujuan untuk memperbaiki kinerjanya sebagai guru, sehingga hasil belajar siswa menjadi meningkat (Sukidin, 2002 \& Sumarno, 2005).

Penelitian ini dilaksanakan dari tanggal 11 Desember 2017 - 8 Januari 2018. Adapun yang menjadi objek penelitian ini adalah siswa kelas XI MIPA 7 SMA Negeri 6 Bandung tahun ajaran 2017/2018 dan siswa yang menjadi sasaran penelitian berjumlah 30 orang.

Untuk memperoleh data yang diharapkan, peneliti menggunakan instrumen sebagai berikut:

1. Format Kegiatan Siswa (FKS)

2. Daftar Chek

3. Catatan Lapangan/Observasi. Catatan lapangan/observasi ini meliputi:

a. Pedoman Observasi keaktifan siswa, dan daftar aktivitas siswa

b. Observasi pelaksanaan model pembelajaran kooperatif yang dilakukan guru 
4. Diskusi balikan antara peneliti/guru dengan observer.

Adapun data yang dikumpulkan dalam penelitian ini adalah data tentang:

1. Penerapan model Kooperatif tipe group investigasi. Informasi tentang data ini bersumber dari peneliti dan observer dengan teknik pengumpulan data melalui observasi dan diskusi. Alat pegumpulan data yang dipergunakan yaitu lembar observasi.

2. Perubahan-perubahan yang terjadi pada hasil belajar siswa kelas XI MIPA 7 SMA Negeri 6 Bandung, setelah diterapkannya model Kooperatif tipe group investigasi. Informasi mengenai data tersebut bersumber pada peneliti dan siswa melalui observasi, hasil Pengerjaan FKS, lembar diskusi balikan, dengan alat bantunya lembar observasi, dan lembar aktivitas siswa.

3. Tanggapanpenelititentangkendala-kendala yang dihadapi ketika mengembangkan model Kooperatif tipe group investigasi pembelajaran Matematika di kelas XI MIPA 7 SMA Negeri 6 Bandung. Informasi mengenai data tersebut bersumber dari alat bantu yang digunakan diantaranya lembar observasi, lembar diskusi balikan, angket, dan lembar tugas. Lembar observasi mencatat kendala-kendala yang dihadapi penulis pada setiap pelaksanaan tindakan selama penelitian. Lembar diskusi balikan mencatat hasil diskusi antara peneliti dan observer mengenai kendala-kendala yang dihadapi, dalam menerapkan model Kooperatif tipe group investigasi. Angket diberikan pada siswa setiap akhir tindakan untuk mengetahui respon siswa.
Setelah melakukan pengumpulan data dengan berbagai teknik pengumpulan data dan alat bantunya, selanjutnya melakukan pengolahan data dengan cara:

1. Mereduksi yaitu data mentah yang diperoleh dari kegiatan observasi yang telah dicatat dalam lembar observasi (catatan lapangan) dan diskusi balikan tentang kegiatan belajar mengajar dan permasalahan yang dihadapi selama pembelajaran dirangkum sehingga mudah dipahami. Pengerjaan FKS siswa diberi skorsesuaikriteriajawaban, yang kemudian dimasukan kedalam lembar penskoran siswa sesuai dengan nama dan skor yang diperoleh oleh setiap siswa. Angket yang telah diisi siswa untuk mengetahui respon siswa terhadap model pembelajaran yang telah dilaksanakan diseleksi, diklarifikasi berdasarkan aspek-aspek permasalahan dan dirangkum sehingga mudah dipahami.

2. Kategorisasi, kegitan ini mengkategorikan siswa sesuai hasil belajar siswa, baik berdasarkan aktivitas dan pengerjaan FKS. Aktifitas siswa dikatagorikan pada aktifitas berdiskusi, menjawab, menentukan kesepakatan hasil investigasi, dan menuliskan jawaban hasil dikusi secara mandiri.

3. Pengambilan kesimpulan dan verifikasi. Kegiatan ini merupakan proses analisis pengaruh penerapan model Kooperatif tipe group investigasi, menjelaskan pola urutan dan mencari hubungan uraian selama penelitian.

Selanjutnya adalah validasi data. Validasi merupakan salah satu syarat penting dalam melaksanakan seluruh jenis penelitian, termasuk dalam penelitian tindakan 
kelas (PTK). Cara atau strategi yng dapat digunakan untuk menentukan validitasi data yaitu members check, triangulasi dan audit trail.

Terakhir adalah interpretasi data. Pada tahap ini peneliti berusaha menginterprestasikan temuan-temuan data penelitian berdasarkan kerangka teoritik yang dipilih dengan mengacu pada normanorma praktis yang disetujui. Adapun indikator keberhasilan penelitian tindakan ini adalah ketuntasan belajar. Artinya, suatu

kelas disebut telah tuntas belajarnya bila kelas tersebut telah mencapai $85 \%$ siswa mencapai daya serap (Depdikbud RI, 1994). Untuk menghitung persentase diatas dapat menggunakan rumus sebagai berikut:

Tingkat penguasaan $=\frac{\text { Jumlah skor total subjek } \times 100 \%}{\text { Jumlah skor total maksimal }}$

Secara prosedural, penelitian ini mengunakan sistem spiral refleksi model Kemmis dan Mc Taggart dikutip Sukidin dkk (2002).

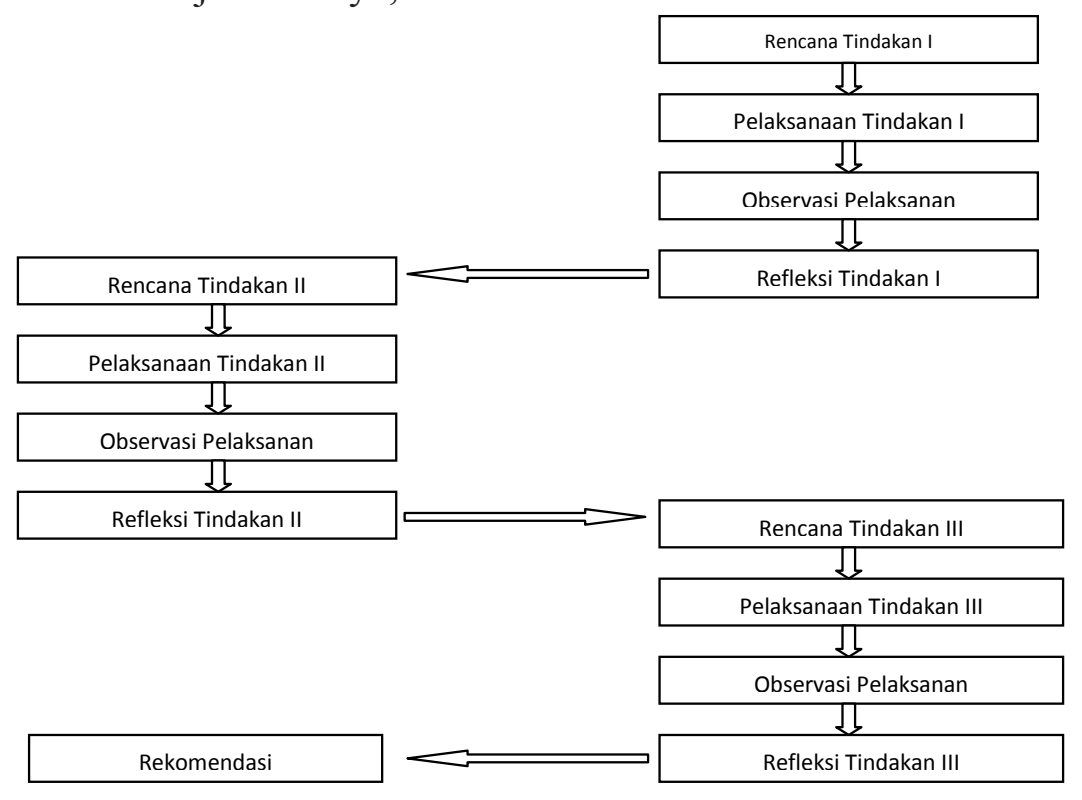

Gambar 1

Prosedur Pengembangan Model Tindakan (Sumarno, 2005).

Prosedur penelitian pada gambar 1 dapat diterjemahkan sebagai berikut:

1. Perencanaan yaitu menyusun rencana tindakan meliputi menyusun perencanaan dimulai dari pembuatan rencana pembelajaran, lembar tugas siswa, angket tanggapan siswa, format observasi pelaksanaan pembelajaran oleh guru dan siswa, media, format tes, serta instrumen lainnya yang dibutuhkan selama penelitian dilakukan. Penyusunan tersebut dilakukan bekerja sama antara penulis dengan observer.
2. Pelaksanan tindakan yaitu praktek pembelajaran yang nyata berdasarkan rencana tindakan yang telah disusun sebelumnya secara bersama. Dalam kegiatan ini, penulis dan siswa melaksanakan kegiatan belajar mengajar sesuai dengan silabus dan rencana pengajaran yang disepakati antara penulis dan observer. Observer mengamati aktivitas siswa dan penulis, selama kegiatan belajar mengajar berlangsung.

3. Observasi merupakan mendokumentasikanproses, pengaruh, kendala, tindakan, 
serta persoalan yang mungkin ada. Pada saat observasi, observer mengamati proses pembelajaran berlangsung dengan mencatat kegiatan yang dilaksanakan oleh Penulis dan siswa, serta mencatat kendala-kendala yang dihadapi penulis dalam mengembangkan model Kooperatif tipe group investigasi dengan pemberian tugas (soal). Selain itu observer memberi nilai berupa angka satu (1) pada siswa yang melakukan aktivitas berdiskusi, menjawab, menentukan kesepakatan hasil investigasi, dan menuliskan jawaban hasil dikusi secara mandiri. Hasil observasi itu mendasari refleksi untuk tindakan yang telah dilakukan dan dijadikan pertimbangan untuk menyusun rencana tindakan selajutnya.

4. Rekomendasi yaitu menjelaskan setiap kegagalan pelaksanaan dan efekefeknya (refleksi). Penulis dan observer mendiskusikan kelebihan dan kekurangan serta pengaruhnya dalam kegiatan belajar mengajar pada setiap tindakan selama penelitian dilaksanakan.

Penelitian ini dilaksanakan dari tanggal 11 Desember 2017 - 8 Januari 2018. Adapun yang menjadi objek penelitian ini adalah siswa kelas XI MIPA 7 SMA Negeri 6 Bandung, tahun ajaran 2017/2018. Siswa yang menjadi sasaran penelitian berjumlah 30 orang. Untuk memperoleh data yang diharapkan, maka penelitian ini menggunakan instrumen sebagai berikut:

\section{Format Kegiatan Siswa (FKS)}

2. Daftar Chek

3. Catatan Lapangan/Observasi. Catatan lapangan/observasi ini meliputi:

a. Pedoman Observasi keaktifan siswa, dan daftar aktivitas siswa

b. Observasi pelaksanaan model pembelajaran kooperatif yang dilakukan guru

4. Diskusi balikan antara penulis/guru dengan observer.

Adapun data yang dikumpulkan dalam penelitian ini adalah data tentang:

1. Penerapan model Kooperatif tipe group investigasi. Informasi tentang data ini bersumber dari penulis dan observer dengan teknik pengumpulan data melalui observasi dan diskusi. Alat pegumpulan data yang dipergunakan yaitu lembar observasi.

2. Perubahan-perubahan yang terjadi pada hasil belajar siswa kelas XI MIPA 7 SMA Negeri 6 Bandung, setelah diterapkannya model Kooperatif tipe group investigasi. Informasi mengenai data tersebut bersumber pada Penulis dan siswa melalui observasi, hasil Pengerjaan FKS, lembar diskusi balikan, dengan alat bantunya lembar observasi, dan lembar aktivitas siswa.

3. Tanggapan peneliti tentang kendalakendala yang dihadapi ketika menerapkan model Kooperatif tipe group investigasi pada pembelajaran Matematika, di kelas XI MIPA 7 SMA Negeri 6 Bandung. Informasi mengenai data tersebut bersumber dari alat bantu yang digunakan diantaranya lembar observasi, lembar diskusi balikan, angket, dan lembar tugas. Lembar observasi mencatat kendala-kendala yang dihadapi penulis pada setiap pelaksanaan tindakan selama penelitian. Lembar diskusi balikan mencatat hasil diskusi antara penulis dan observer mengenai kendala-kendala yang dihadapi, dalam menerapkan model 
Kooperatif tipe group investigasi. Angket diberikan pada siswa setiap akhir tindakan untuk mengetahui respon siswa.

Setelah melakukan pengumpulan data dengan berbagai teknik pengumpulan data dan alat bantunya, selanjutnya melakukan pengolahan data dengan cara:

1. Mereduksiyaitu data mentahyang diperoleh dari kegiatan observasi yang telah dicatat dalam lembar observasi (catatan lapangan) dan diskusi balikan tentang kegiatan belajar mengajar dan permasalahan yang dihadapi selama pembelajaran dirangkum sehingga mudah dipahami. Pengerjaan FKS siswa diberi skor sesuai kriteria jawaban, yang kemudian dimasukan kedalam lembar penskoran siswa sesuai dengan nama dan skor yang diperoleh oleh setiap siswa. Angket yang telah diisi siswa untuk mengetahui respon siswa terhadap model pembelajaran yang telah dilaksanakan diseleksi dan diklarifikasi berdasarkan aspek-aspek permasalahan serta dirangkum sehingga mudah dipahami.

2. Kategorisasi, kegitan ini mengkategorikan siswa sesuai hasil belajar, baik berdasarkan aktivitas dan pengerjaan FKS siswa. Aktifitas siswa dikategorikan pada aktifitas berdiskusi, menjawab, menentukan kesepakatan hasil investigasi, dan menuliskan jawaban hasil dikusi secara mandiri.

3. Pengambilan kesimpulan dan verifikasi. Kegiatan ini merupakan proses analisis pengaruh penerapan model Kooperatif tipe group investigasi dan menjelaskan pola urutan dan mencari hubungan uraian selama penelitian.

Selanjutnya adalah validasi data. Validasi merupakan salah satu syarat penting dalam melaksanakan seluruh jenis penelitian, termasuk dalam penelitian tindakan kelas (PTK). Cara atau strategi yng dapat digunakan untuk menentukan validitas yaitu members check, triangulasi dan audit trail.

Terakhir adalah interpretasi data. Pada tahap ini peneliti berusaha menginterprestasikan temuan-temuan data penelitian berdasarkan kerangka teoritik yang dipilih dengan mengacu pada norma-norma praktis yang disetujui. Adapun indikator keberhasilan penelitian tindakan ini adalah ketuntasan belajar. Dengan kata lain, suatu kelas disebut telah tuntas belajarnya bila kelas tersebut telah mencapai $85 \%$ siswa mencapai daya serap (Depdikbud RI, 1994). Untuk menghitung persentase diatas dapat menggunakan rumus sebagai berikut:

Tingkat penguasaan $=\frac{\text { [umlah skor total subjek } \times 100 \%}{\text { jumlah skor total maksimal }}$

\section{HASIL DAN PEMBAHASAN}

\section{Aktivitas Siswa dalam Penerapan Model Kooperatif Tipe Group Investigasi pada Tindakan I-III}

Model pembelajaran kooperatif tipe group investigasi merupakan sebuah bentuk pembelajaran kooperatif dimana siswa membentuk kelompok kepentingan untuk merencanakan, melaksanakan investigasi dan mensintesis temuan kedalam presentasi kelas. Hariyanto (2000) mengungkapkan bahwa model investigasi kelompok menawarkan agar dalam mengembangkan masalah moral dan sosial, di mana siswa diorganisasaikan dengan cara melakukan penelitian bersama atau "cooperative inquiry" terhadap masalahmasalah sosial dan moral, maupun masalah 
akademis.

Berdasar penelitian dari Asyari (2016) penerapan group investigasi bersama dengan Problem Based Learning dalam pembelajaran telah mendorong siswa untuk berpikir kritis melalui merencanakan, berdebat, mengemukakan pertanyaan dan masalah, dan menganalisa dan memberikan solusi kepada lingkungan sekitarnya. Lebih lanjut Johnson dan Johnson. dalam (Retno, 2003) model pembelajaran kooperatif tipe group investigasi memiliki berbagai pengaruh positif terhadap perkembangan anak, pengaruh tersebut diantaranya adalah: meningkatkan prestasi belajar, meningkatkan daya ingat (retensi) dan lebih dapat digunakan untuk mencapai taraf penalaran lebih tinggi. Hal ini diperkuat dengan pendapat Stahl (dalam Hariyanto, 2000), bahwa model belajar Kooperatif tipe group investigasi menempatkan siswa sebagai bagian dari suatu sistem kerjasama dalam mencapai suatu hasil yang optimal dalam belajar.

$\begin{array}{clc}\text { Adapun langkah-langkah } & \text { Mode } \\ \text { pembelajaran } & \text { kooperatif tipe group }\end{array}$

\section{Tabel 1}

Aktivitas Siswa Selama Pembelajaran Dari Tindakan I-III

\begin{tabular}{|c|c|c|c|c|c|c|c|c|c|c|c|c|}
\hline \multirow{3}{*}{$\begin{array}{c}\text { Jumlah } \\
\text { Siswa \& } \\
\text { Prosentase } \\
\end{array}$} & \multicolumn{12}{|c|}{ Aktivitas Siswa Selama Pembelajaran pada Tindakan I - III } \\
\hline & \multicolumn{3}{|c|}{ Berdiskusi } & \multicolumn{3}{|c|}{$\begin{array}{l}\text { Melakukan } \\
\text { investigasi }\end{array}$} & \multicolumn{3}{|c|}{$\begin{array}{l}\text { Menentukan } \\
\text { kesepakatan hasil } \\
\text { investigasi }\end{array}$} & \multicolumn{3}{|c|}{ Menuliskan Jawaban } \\
\hline & I & II & III & I & II & III & I & II & III & I & II & III \\
\hline Jumlah & 18 & 22 & 26 & 15 & 20 & 25 & 13 & 19 & 23 & 16 & 23 & 28 \\
\hline $\begin{array}{l}\text { Siswa } \\
\text { Prosentase }\end{array}$ & 60.00 & 73.33 & 86.67 & 50.00 & 66.67 & 83.33 & 43.33 & 63.33 & 76.67 & 53.33 & 76.67 & 93.33 \\
\hline
\end{tabular}

Berdasarkan data pada Tabel 1, aktivitas siswa mulai dari berdiskusi, melakukan investigasi, menentukan kesepakatan hasil investigasi, dan menuliskan jawaban investigasi adalah (Slavin, 2010):

1. Membuat kelompok heterogen dengan orientasi tugas

2. Pengarahan untuk merencanakan pelaksanaan investigasi

3. Tiap kelompok menginvestigasi tugas yang diberikan guru

4. Tiap kelompok menentukan kesepakatan hasil investigasi

5. Persentasi hasil kesepakatan kelompok

Dari penelitian, keaktifan siswa dalam menerapkan model Kooperatif tipe group investigasi pemberian tugas dari tindakan pertama sampai tindakan ketiga menunjukkan peningkatan. Keaktifan siswa terlihat dari aktivitas siswa selama proses pembelajaran berlangsung dengan melakukan aktitas menyimak, memberi pertanyaan, maupun menjawab pertanyan lisan dari Penulis dan temannya. Berdasarkan hasil observasi selama penelitian dari tindakan pertama sampai ketiga, aktivitas siswa selama pembelajaran Matematika dapat dilihat pada tabel 1. 
75\%. Peningkatan ini dikarenakan kerjasama kelompok dalam pembelajaran kooperatif dengan metode Group Investigation dapat membangkitkan semangat siswa untuk memiliki keberanian dalam mengemukakan pendapat dan berbagi informasi dengan teman lainnya dalam membahas materi pembelajaran (Slavin, 2010), sehingga suasana belajar terasa lebih efektif. Selain itu, Sebuah aspek terpenting dalam pembelajaran koopertif adalah membantu meningkatkan kebiasaan bekerja sama dan hubungan yang baik antar anggota kelompok. Tujuan kelompok dan pertanggungjawaban individu mendorong siswa untuk saling membantu dan bekerja yang terbaik untuk dirinya dan kelompoknya (Hariyanto, 2000).

\section{Skor keseluruhan Hasil Pengerjaan FKS}

\section{Siswa dari Tindakan I - III}

Nilai siswa kelas XI MIPA 7 dari tindakan I - tindakan III dapat dilihat pada Tabel 2.

Tabel 2

Nilai Siswa dari Tindakan I - Tindakan III

\begin{tabular}{|c|c|c|c|c|}
\hline \multirow{2}{*}{ No } & \multirow{2}{*}{ Nama Siswa } & \multicolumn{3}{|c|}{ Nilai Siswa } \\
\hline & & Tindakan I & Tindakan II & Tindakan III \\
\hline 1 & Akhmad Yamani & 5 & 6 & 7.5 \\
\hline 2 & Alda Nabilah & 4 & 5 & 6 \\
\hline 3 & Alifia Syifa & 6.5 & 7.5 & 9 \\
\hline 4 & Azkia Diana & 6.5 & 7.5 & 8.5 \\
\hline 5 & Davina Putri & 6.5 & 7.5 & 9 \\
\hline 6 & Disa Rosseti & 6.5 & 7.5 & 9 \\
\hline 7 & Farisa Abiyah & 6.5 & 7 & 7.5 \\
\hline 8 & Ghinna Sahara & 5.5 & 6.5 & 7.5 \\
\hline 9 & Gita Audri & 4 & 5.5 & 6 \\
\hline 10 & Hally Hasbially & 5 & 6.5 & 7.5 \\
\hline 11 & Karina Albi & 5 & 6.5 & 7.5 \\
\hline 12 & Lathifah Fadhilah & 4 & 5.5 & 6.5 \\
\hline 13 & Muh Adji & 6.5 & 7.5 & 9 \\
\hline 14 & Muh Adrian & 5 & 6.5 & 7.5 \\
\hline 15 & Muh Fajar & 5.5 & 6.5 & 7.5 \\
\hline 16 & Muh Reza & 4 & 5.5 & 6 \\
\hline 17 & Nadhif Pratama & 5 & 6.5 & 8.5 \\
\hline 18 & Neva Chairunnisa & 6.5 & 7 & 7.5 \\
\hline 19 & Nida Nurhafizah & 5.5 & 6.5 & 7.5 \\
\hline 20 & Paula Sekar & 6.5 & 7 & 8.5 \\
\hline 21 & Raihan Ilham & 6.5 & 7 & 8.5 \\
\hline 22 & Raisya Violetta & 6.5 & 7 & 8.5 \\
\hline 23 & Riyad Anugrah & 6.5 & 7.5 & 9 \\
\hline 24 & Shafira Nadia & 6.5 & 7 & 7.5 \\
\hline 25 & Tiara Aisyah & 5 & 6 & 6.5 \\
\hline 26 & Valent Vebrilian & 6.5 & 7 & 7.5 \\
\hline 27 & Yosep Kristiadi & 4 & 6.5 & 7.5 \\
\hline 28 & Yudha Pratama & 6.5 & 7 & 8.5 \\
\hline 29 & Yusi Rindiawati & 6.5 & 7.5 & 9 \\
\hline 30 & Zulfan Muhamad & 4 & 5.5 & 6 \\
\hline & RATA-RATA & 6.17 & 6.98 & 7.85 \\
\hline & DSK & $50.00 \%$ & $66.67 \%$ & $90.00 \%$ \\
\hline
\end{tabular}

Nilai pada Tabel di atas dilihat dari skor skor rata-rata siswa kelas XI MIPA 7 dapat rata-rata mengalami peningkatan. Adapun dilihat pada Tabel 3 . 
Tabel 3

Skor Rata-rata Pengerjaan FKS Siswa dari Tindakan I - III

\begin{tabular}{ccc}
\hline \multicolumn{3}{c}{ Skor rata-rata Pengerjaan FKS siswa kelas XI MIPA 7 } \\
\hline Tindakan I & Tindakan II & Tindakan III \\
6.17 & 6.98 & 7.85 \\
\hline
\end{tabular}

Tabel 3 di atas apabila dirubah menjadi berikut : bentuk diagram maka hasilnya sebagai

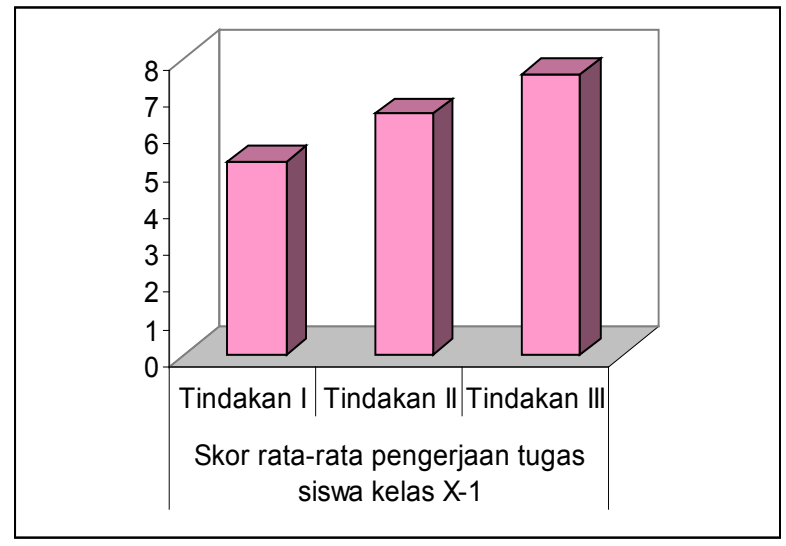

Gambar 2

Skor Rata-rata Pengerjaan FKS Siswa dari Tindakan I - III

Berdasarkan tabel 3 dan gambar 2 diatas, skor yang diperoleh siswa dari tindakan pertama sampai pada tindakan ketiga mengalami peningkatan. Pada tidakan I skor rata-rata siswa kelas XI MIPA 7 sebesar 6.17. Pada tindakan II sebesar 6.98. Pada tidakan III menjadi 7.85. Hal ini menunjukkan bahwa pembelajaran dengan metode group investigation dapat meningkatkan hasil belajar siswa. Setiawan (2006: 6) menyebutkan dengan menggunakan group investigation rasa percaya diri diri dapat meningkat dan adanya pembagian kerja antar siswa dalam kelompok sehingga siswa tertib dalam mengikuti proses pembelajaran kelas XI MIPA 7.

\section{Kendala-kendala yang Dihadapi (Penulis)} Guru dalam Mengembangkan Model

\section{Kooperatif tipe group investigasi}

Kendala-kendala yang dihadapi peneliti dalam menerapkan model Kooperatif tipe group investigasi pemberian tugas pada pembelajaran Matematika di kelas XI MIPA 7 SMA Negeri 6 Bandung didapatkan melalui hasil observasi, diskusi balikan dan angket.

Menurut observer, kendala-kendala yang dihadapi peneliti dalam setiap tindakan dapat dilihat kembali pada pembahasan refleksi dan revisi pada setiap tindakan. Pada awal dilaksakannya model Kooperatif tipe group investigasi pemberian tugas dalam pembelajaran Matematika, peneliti mengalami kesulitan yaitu peneliti belum bisa menangani respon siswa terhadap penerapan model Kooperatif tipe group investigasi pemberian tugas dan belum memotivasi siswa untuk aktif berpartisifasi mengikuti jalannya proses pembelajaran sehingga suasanan kelas belum tertib dan kondusif. Pada tindakan II sampai III kesulitan yang dihadapi penulis pada tindakan I telah diperbaiki.

Kendala-kendala yang tidak hanya dihadapi peneliti, siswa sendiri pada tindakan 
I belum beradaptasi dengan diterapkannya model kooperatif tipe group investigasi pemberian tugas yang dikerjakan dikelas. Siswa tidak aktif seluruhnya untuk mengikuti semua sesi pembelajaran, mulai dari berdiskusi, menjawab pertanyaan siswa lain, menentukan kesepakatan hasil investigasi dan menuliskan jawaban hasil diskusi secara mandiri. Mereka belum kompak untuk menjawab setiap soal dari FKS secara berkelompok dengan cara berdiskusi. Selain itu, mereka mengalami kesulitan karena tidak pernah membaca terlebih dahulu di rumah materi yang akan dipelajari disekolah sehingga selama pengerjaan FKS terlihat siswa kesulitan menemukan informasi sesuai pertanyaan-pertanayaan yang tercantum dalam lembar tugas.

Berdasarkan hasil observasi pada tindakan II sampai III, siswa tidak lagi mengalami kesulitan dengan diterapkannya model kooperatif tipe group investigasi melalui model pemberian tugas. Mereka sudah kompak dan saling membantu untuk menjawab setiap soal pada FKS dengan cara berdiskusi dengan anggota kelompoknya. Sebagaimana menurut Slavin (2010) model pembelajaran kooperatif merupakan salah satu model pembelajaran dimana siswa belajar dan bekerja dalam kelompok-kelompok kecil secara kolaboratif yang anggotanya terdiri dari empat sampai enam orang, dengan struktur kelompok yang bersifat heterogen. Di sisi lain, guru/ peneliti telah memberikan bimbingan dan arahan secara intensif kepada setiap siswa dengan cara berkeliling untuk membantu siswa-siswi yang mengalami kesulitan.

\section{SIMPULAN}

Berdasarkan hasil penelitian tindakan kelas yang telah dilakukan dapat disimpulkan bahwa; (1) Keaktifan dan hasil belajar siswa pada pembelajaran Matematika di kelas XI MIPA 7 SMA Negeri 6 Bandung meningkat. Keaktifan siswa terlihat dari aktivitas siswa selama proses pembelajaran berlangsung dengan melakukan aktitas menyimak, memberi pertanyaan, maupun menjawab pertanyan lisan dari Penulis dan temannya Sedangkan peningkatan skor pengerjaan FKS terjadi karena siswa telah melaksanakan langkah-langkah proses pembelajaran kooperatif dengan benar, aktif mengikuti setiap sesi pembelajaran mulai dari berdiskusi, saling memberi dan menerima jawaban dari setiap soal pada FKS, menentukan kesepakatan hasil investigasi jawaban yang dilontarkan siswa lain masih dalam satu kelompok, serta menuliskan jawaban hasil diskusi secara mandiri; (2) Tanggapan siswa kelas XI MIPA 7 SMA Negeri 6 Bandung terhadap model pembelajaran kooperatif yang diterapkan menunjukkan sikap yang positif; (3) Terjadi perubahan dalam pembelajaran Matematika setelah siswa menggunakan model belajar kooperatif yaitu, siswa tidak lagi mengalami kesulitan dengan diterapkannya model Kooperatif tipe group investigasi melalui model pemberian tugas, mereka sudah kompak dan saling membantu untuk menjawab setiap soal pada FKS dengan cara berdiskusi, dengan anggota kelompoknya. Kemudian guru/penulis telah memberikan bimbingan dan arahan secara intensif kepada setiap siswa dengan cara berkeliling untuk membantu siswa-siswi yang mengalami kesulitan 


\section{DAFTAR RUJUKAN}

Abdurrahman. (1989). Pendidikan Bagi Anak Berkesulitan Belajar. Rineka Cipta. Jakarta.

Arikunto, S. (2003). Dasar-Dasar Evaluasi Pendidikan. Jakarta: Bumi Aksara

Asyari, M. (2016). Improving critical thinking skills through the integration of problem based learning and group investigation. International Journal for Lesson and Learning Studies. 5 (1), hlm. 36-44.

Cerbin, W. \& Kopp, B. (2006). Lesson study as a model for building pedagogical knowledge and improving teaching. International Journal of Teaching and Learning in Higher Education, 18 (3), hlm. 250-257.

Dahar, R. W. (1985). Teori-Teori Belajar. Jakarta: Erlangga.

Harianto. (2000). Media Pengajaran dan Model-model Pembelajaran. P2TK. Jakarta: Depdikbud.

Hariyanto. (2000). Perbandingan Hasil Belajar Matematika Antara Siswa yang Pembelajarannya Mengguanakn Model Kooperatif tipe group investigasi Tipe Jigsaw dengan model Tradisional di Kelas II Man Jember. Tesis UPI Bandung. Tidak Diterbitkan.

Kronberg, J. \& Griffin, M. (2000). Analysis problems, a means to developing students' criticalthinking skills. Journal of College Science Teaching, 24 (5), hlm. 348-352.

Murtiani, M., F, A \& Wulan, R. (2012), "Penerapan Pendekatan contextual teaching and learning (CTL) berbasis lesson study dalam Meningkatkan Kualitas Pembelajarn Fisika di SMP Negeri Kota Padang”, Jurnal Penelitian Pembelajaran Fisika, 1 (2012) hlm. 1-21.

Ono, Y. \& Ferreira, J. (2010), “A case study of continuing teacher professional development through lesson study in South Africa”, South African Journal of Education, Vol. 30.

Retno. (2003). Media Pendidikan dan Model Pembelajaran, Pengertian, Pengembangan, dan Pemanfaatannya. Jakarta: Rajawali.

Saraswati. (2000). Pendidikan Konstruktivisme dengan Penerapan Kooperatif dalam Konteks Sets. Bandung: Depdikbud.

Sato, M. (2014). Mereformasi Sekolah, Konsep dan Praktek Komunitas Belajar. (Terjemahan oleh Djafri F.), PELITA/JICA.

Slavin, R. E. (2010). Coopertive Learning. Bandung: Nusa Media

Sudjana, (2001). Penelitian dan Penilaian Pendidikan. Jakarta: Sinar Baru.

Sukidin. (2002). Manajemen Penelitian Tindakan Kelas. Jakarta: Insan Cendikia.

Sumantri \& Permana. (2001). Strategi Pembelajaran. Jakarta: Sinar Baru.

Sumarno, U. (2005). Penelitian Tindakan Kelas. Makalah. FPMIPA UPI. Tidak diterbitkan

Udin, S. W. (1992). Strategi Belajar Mengajar IPA. Jakarta: Depdikbud.

Winkell, W. S. (1993). Psikologi Pengajaran. Jakarta: Gramedia.

Wiriaatmadja. (1999). Penelitian Kelas dalam Bentuk Penelitian Tindakan Sebagai Upaya Meningkatkan Kemahiran Profesional Dosen di Perguruan Tinggi. Jurnal Mimbar Penelitian. No 30. Bandung. UPI Bandung

Wasamana \& Nurihsan, J. (2016). Metode Pembelajaran Investigasi Kelompok untuk Meningkatkan Kecakapan Sosial Siswa Sekolah Dasar. Jurnal Penelitian Pendidikan. 16 (2), hlm 102-109. 